\title{
Theoretical and Methodological Aspects of Innovation Development in Modern Economic Systems
}

\author{
Irina V. Gashenko', Svetlana G. Vokina ${ }^{2}$, Dmitry G. Romanov' ${ }^{1}$, Tatiana L. Bezrukova ${ }^{3}$, Yuri A. Kozenko ${ }^{4}$
}

ABSTRACT

The purpose of this article is to classify existing approaches to analyzing theoretical and methodological aspects of innovation development in modern economic systems. We also present a new approach based on existing ones that combines advantages, eliminates drawbacks, and offers means of analyzing innovation development in modern economic systems and that presents optimal models of innovation development in modern economic systems.

The authors develop and approbate - based on the case of present-day Russia - proprietary methodologies for examining innovation development in modern economic systems. It involves the calculation of an index of innovation development that reflects current levels of innovation development in economic systems and possibilities and perspectives related to innovation development in economic systems in the near future.

The authors classify approaches to the analysis of theoretical and methodological aspects of innovation development in modern economic systems as criteria on innovation development in economic systems. Within this classification, the authors distinguish between and conduct comparative analyses of the following three main approaches: plan-factual, ranking, and indexing, which involve making various theoretical assumptions on innovation development in modern economic systems and on the use of various methodologies.

The authors present a new approach to the analysis of theoretical and methodological aspects of innovation development in modern economic systems that eliminate drawbacks of existing approaches and that present unique advantages (simple calculations and universal use). In turn, an optimal model of innovation development in modern economic systems is offered.

KEY WORDS: innovation development, modern economic system, human capital, economic growth

JEL Classification: $\quad 0110,0320$

${ }^{1}$ Rostov State Economic University, Russia; ${ }^{2}$ Plekhanov Russian University of Economics, Russia; ${ }^{3}$ Voronezh State University of Forestry and Technologies named after G. F. Morozov, Russia; ${ }^{4}$ Volgograd State Agrarian University, Russia

\section{Introduction}

A priority of any modern economic system and global $\square$ economy is to improve the population living standards.

Correspondence concerning this article should be addressed to: Tatiana L. Bezrukova, Voronezh State Academy of Forestry Engineering, 8 Timiryazeva St., Voronezh 394087, Russia. Tel/fax: +7 (473) 225-39-03. E-mail: bezrukova_t_l@mail.ru
This first involves increasing rates of economic growth and GDP per capita, in turn improving the set of goods and services accessible to each consumer. Second, it involves the creation of innovations that satisfy public needs even while preserving rates of economic growth and creating a stable set of goods and services accessible to consumers. Both processes involve innovation development. 
Absolute and relative increases in GDP occur through scientific research and the development of human resources enterprises, which increase intellectual capital, which promote capabilities for the development of innovations, and which promote adaptations to new technologies and equipment and their application through the creation of innovative technologies of production. Such technologies increase labor efficiency, and the modernization of equipment expands enterprise production capacities. This, in turn, facilitates innovation development within existing spheres of the economy and the refinement of existing products, technologies, and equipment.

The creation of innovations occurs through scientific and educational development in economic systems; through the financing of economic research at corporate and state levels for the development of new products, technologies, and equipment that satisfy consumer needs or existing needs more efficiently; and through the creation of new economic spheres. As a result, scientific revolutions occur, and technological modes change one another.

When taking into account capacities for innovation development in modern economic systems, the efforts of multiple representatives of scientific societies are aimed at theoretical considerations and instrumental developments for the provision of innovation development in modern economic systems. However, the results of previous studies often contradict one another, and accumulated knowledge in this sphere is scattered. This complicates the selection of optimal criteria and of practical applications of existing analysis methodologies focused on innovation development in modern economic systems, predetermining the necessity for their reconsideration and systematization.

The purpose of this article is to classify existing approaches to the analysis of theoretical and methodological aspects of innovation development in modern economic systems and to present a new approach based on existing methods that applies their advantages, eliminates their drawbacks, and includes means for analyzing of innovation development in modern economic systems and optimal models of innovation development in modern economic systems.

\section{Literature review}

Issues of innovation development have been thoroughly studied by scientists in recent years. Various organizational-, production-, and marketing-focused innovation activities employed in enterprises in various countries and economic spheres have been explored at the local scale to support or increase firm competitiveness while preserving or improving firm positions in the market (Allan, Crouchley, \& Robertson 2012; Bayev \& Podshivalova, 2013; Morozova \& Vladimirivna, 2014; Nechaev \& Antipina, 2015; Ryapukhina, Suprun, Doroshenko, Bukhonova, \& Somina, 2015). Enterprise innovation activities are conducted through organizational, production, and marketing activities (Tovt, 2014) to support or increase competitiveness (Belkin \& Belkina, 2013) while also preserving or improving firm market positioning (Imanbekova, 2014).

Other scientists have analyzed basic characteristics, essential peculiarities, and generalized features of innovation development processes at the macro level to determine the role of innovation in the provision of national economic growth and have studied ways of provisioning country competitiveness in the global economy through the creation and application of innovations into national production and through the stimulation of business innovation activities through state policies (Coccia, 2015; Donate, Peña, \& Sánchez de Pablo, 2016; Kolychev \& Prokhorov, 2015; Rumyantsev, 2015; Vasin \& Gamidullaeva, 2015). Innovations play a key role in the provisioning of national economic growth (Ng, Kanagasundram, Wong, \& Chandran, 2015). Increased state competitiveness in the global economy is largely achieved through the creation and application of innovations in national production (Filinova, Filinov, Pogodina, Lunev, \& Luneva, 2015) and through the stimulation of innovative business activities through state policies ( Turriago-Hoyos, Thoene, Bernal-Torres, \& AlfonsoLizarazo, 2015).

Numerous scientific studies have focused on global aspects of innovation development related to overcoming disproportionate economic growth in various countries through innovation and related to global economic growth not only through quantitative expression or an increase in GDP growth but also through qualitative expression through the applica- 
tion of innovations (e.g., (Al-Sudairi \& Bakry, 2014; Machado Arroio, 2012; Parrilli, Nadvi, \& Yeung, 2013; Popkova, Zubakova, Bogdanov, Yakoleva, \& Nebesnay, 2013; Popkova, Yurev, Stepicheva, \& Denisov, 2015; Voegtlin \& Scherer, 2015). At the global scale, innovation involves overcoming disproportionate economic growth in various countries (Yakovleva, Azarova, \& Titova, 2015) and ensuring global economic growth (Ryneiska, 2014) not only in quantitative terms through increases in GDP growth but also in qualitative terms (Voegtlin \& Scherer, 2015).

Issues relating to the functioning and development of modern economic systems have been actively studied in the context of determining common features, unique possibilities, and key tendencies and in terms of identifying significant factors of development based on statistics of economic growth, dynamics of economic system change, models of current states and structures and forecasts of changes to occur in the near future (Hu, 2013; Mishra \& Narayan, 2015; Oxenstierna, 2015; Rommel, 2015; Saikevych, 2012; Zakharova, Prokhorova, Shutilov, \& Klochko, 2015). Modern economic systems develop according to market types involved, and this supposes free competition and minimal interference with market processes (Batkovskiy, Konovalova, Semenova, Trofimets, \& Fomina, 2015). This also assumes the occurrence of periods of crisis and economic growth (Loasby, 2015). Innovations are some of the most significant developmental factors affecting modern economic systems (Okrepilov, Makarov, Bakhtizin, \& Kuzmina, 2015).

Nevertheless, despite the numerous studies conducted on this topic, theoretical and methodological aspects of innovation development in modern economic systems have not been studied in a consistent or systemic way. Research conducted in this sphere is thus fragmented, raising the necessity for a systematization of accumulated knowledge for the creation of nuanced and comprehensive understandings of problems, perspectives, and methods related to the activation of innovation activities in modern economic systems. This is examined in this article.

\section{Method}

As methodological instruments, the authors apply induction, deduction, problem and systemic analysis, classification, formalization, economic modeling and forecasting. In addition to the above methods, we use the proprietary method of innovation development analysis in modern economic systems. This approach involves the calculation of indexes of innovation development, which reflect current levels of innovation development in economic systems and perspectives on innovation development in economic systems to develop in the near future:

Iinnov $=(\mathrm{SE}+\mathrm{SF}+\mathrm{IT} / \mathrm{CT})+\left(\mathrm{IE}_{5} / \mathrm{IE}_{1}+\mathrm{QP}_{5} / \mathrm{QP}_{1}+\mathrm{FS}_{5} / \mathrm{FS}_{1}\right)$

where

Iinnov - index of innovation development in an economic system;

SE - share of innovation enterprises to the total number of enterprises in an economic system;

$\mathrm{SF}$ - share of expenditures for financing science in the form of GDP;

CT - number of leading production technologies created in the current year;

IT - number of leading production technologies applied through enterprise activities in the current year; IE - number of innovation enterprises (1 - in the first year, 5 - in 5 years)

QP - quantity of personnel focused on scientific research and development ( 1 - in the first year, 5 - in 5 years)

FS - financing of science from state budget assets ( 1 - in the first year, 5 - in 5 years).

Indicators of innovation development and generated innovation development index values are evaluated using a special scale (Tables 1 and 2). The index generates values of 6 to 30. The higher the index value, the higher the level and the more significant perspectives on innovation development are in an economic system.

\section{Results}

In this study, the authors classify approaches to the analysis of theoretical and methodological aspects of innovation development in modern economic systems as criteria for innovation development in economic systems (Table 3 ). Within this classification, the following three main approaches are identified: plan-factual, ranking, and indexing approaches. These approaches involve applying various theoretical definitions of innovation development in modern economic systems and various methodologies. 
Table 1. Scale for evaluating values of indicators of innovation development in modern economic systems

\begin{tabular}{lccccc}
\hline & \multicolumn{5}{c}{ Values assigned to indicators } \\
\cline { 2 - 5 } Indicators & $\mathbf{1}$ & $\mathbf{2}$ & $\mathbf{3}$ & $\mathbf{4}$ & $\mathbf{5}$ \\
\hline $\mathrm{nE}$ & $<1 \%$ & $1 \%-9 \%$ & $10 \%-24 \%$ & $25 \%-50 \%$ & $>50 \%$ \\
$\mathrm{SF}$ & $<0.5 \%$ & $0.5 \%-0.9 \%$ & $1-2.9 \%$ & $3 \%-5 \%$ & $>5 \%$ \\
$\mathrm{IT/CT}$ & $<0.50$ & $>100$ & $0.50-0.99$ & $50-100$ & $1-50$ \\
$\mathrm{IE} / \mathrm{IE}$ & $<0.80$ & $0.80-0.99$ & $1.00-1.19$ & $1.20-1.49$ & $>1.50$ \\
$\mathrm{QP}_{5} / \mathrm{QP}_{1}$ & $<0.80$ & $0.80-0.99$ & $1.00-1.19$ & $1.20-1.49$ & $>1.50$ \\
$\mathrm{FS}_{5} / \mathrm{FS}_{1}$ & $<0.80$ & $0.80-0.99$ & $1.00-1.19$ & $1.20-1.49$ & $>1.50$ \\
\hline
\end{tabular}

Table 2. Scale for evaluating values of indexes of innovation development in modern economic systems

\begin{tabular}{cl}
\hline linnov Values & Innovation development: current levels and perspectives \\
\hline $6-10$ & critical lack and absence of innovation development perspectives \\
$11-14$ & limited or absent innovation development perspectives \\
$15-20$ & limited but good innovation development perspectives \\
$21-26$ & high-level but insignificant innovation development perspectives \\
$27-30$ & high-level and significant innovation development perspectives \\
\hline
\end{tabular}

As Table 3 shows, when applying a plan-factual approach, innovation development in an economic system can be understood as the degree of plan realization. Rather, a model of innovation development in an economic system is created first and is then compared to reality. When applying a ranking approach, innovation development in an economic system is measured through rankings. While this allows one to compare economic systems, it hinders the determination of causal relations. Through the indexing approach, innovation development in an economic system is understood as the value of a certain index. This approach is limited due to challenges associated with procuring statistical data and calculating indices.

Existing approaches to the analysis of theoretical and methodological aspects of innovation development in modern economic systems are most limited in their focus on previous (plan-factual approaches) or current trends (ranking and index approaches) without accounting for future possibilities for innovation development in economic systems and in their basis in economically developed countries, rendering them inapplicable developing countries.

To overcome these drawbacks, we present a new proprietary approach to the analysis of theoretical and methodological aspects of innovation development in modern economic systems that involves not only the evaluation of current levels but also the determination of potential avenues of innovation development in economic systems. Furthermore, unlike existing approaches, this approach can be applied at the national, regional, and global levels, making it universally applicable.

The proposed approach is based on the calculation of integral indicators of innovation development, en- 
Table 3. Classification of approaches to the analysis of theoretical and methodological aspects of innovation development in modern economic systems

\begin{tabular}{|c|c|c|c|}
\hline \multirow[t]{2}{*}{ Criteria of comparison } & \multicolumn{3}{|c|}{$\begin{array}{l}\text { Approaches to the analysis of theoretical and methodological aspects of innovation } \\
\text { development in modern economic systems }\end{array}$} \\
\hline & Plan-factual approach & Ranking approach & Index approach \\
\hline Approach representatives & $\begin{array}{l}\text { (Vasin \& Gamidullaeva, 2015), } \\
\text { (Ng et al., 2015) }\end{array}$ & $\begin{array}{l}\text { (Donate et al., 2016), } \\
\text { (Turriago-Hoyos et al., 2015), } \\
\text { (Filinova et al., 2015) }\end{array}$ & $\begin{array}{l}\text { (Coccia, 2015), (Rumyantsev, } \\
\text { 2015), (Kolychev \& Prokhorov, } \\
\text { 2015) }\end{array}$ \\
\hline $\begin{array}{l}\text { Determination of } \\
\text { innovation development in } \\
\text { modern economic systems } \\
\text { through the approach }\end{array}$ & $\begin{array}{l}\text { Innovation development in } \\
\text { economic systems - plan } \\
\text { realization }\end{array}$ & $\begin{array}{l}\text { Innovation development in } \\
\text { economic systems - ranking } \\
\text { position }\end{array}$ & $\begin{array}{l}\text { Innovation development in } \\
\text { economic systems -index } \\
\text { values }\end{array}$ \\
\hline $\begin{array}{l}\text { Levels of innovation } \\
\text { development in modern } \\
\text { economic systems } \\
\text { considered through the } \\
\text { approach }\end{array}$ & $\begin{array}{l}\text { Comparison between } \\
\text { factual levels of innovation } \\
\text { development and normative } \\
\text { values and previously } \\
\text { compiled models and plans } \\
\text { on innovation development } \\
\text { in economic systems }\end{array}$ & $\begin{array}{l}\text { - Knowledge assessment } \\
\text { methods (KAM - the } \\
\text { Knowledge Assessment } \\
\text { Methodology) (The } \\
\text { World Bank, 2015); } \\
\text { - } \quad \text { ranking countries } \\
\text { on innovativeness } \\
\text { (Economist Intelligence } \\
\text { Unit, 2015). }\end{array}$ & $\begin{array}{l}\text { - Index of scientific \& } \\
\text { technical potential as a } \\
\text { component of integral } \\
\text { indicators for evaluating a } \\
\text { country's competitiveness } \\
\text { (World Economic Forum, } \\
\text { 2014); } \\
\text { - System for evaluating } \\
\text { innovation activity in } \\
\text { a country based on } \\
\text { indicators of the European } \\
\text { innovation scoreboard } \\
\text { (European Commission, } \\
\text { 2014); } \\
\text { Global innovation index } \\
\text { (Management Today, } \\
\text { 2013). }\end{array}$ \\
\hline
\end{tabular}

suring compatibility with the index approach. However, the new approach involves completing simpler calculations based on generally accessible statistical information on economic systems, and it generates results faster, creating additional advantages and making it more attractive when conducting research.

Let us conduct an evaluation of levels and perspectives of innovation development in present-day Russia using the proposed approach. To calculate the necessary indicators and index of innovation development for the Russian economy, let us use official Federal State Statistics Service statistics for 20102014. Statistical information and analysis results are given in Table 4.
Table 4 shows that in present-day Russia, according to 2010-2014 data, a small share of enterprises conduct scientific research and development and apply innovations - innovation enterprises (less than 1\%). A small share of GDP expenditures is dedicated to financing scientific research (less than $0.5 \%$ ), causing the number of innovations applied to significantly exceed the number of innovations created (135 times). This shows that in Russia, innovation development does not receive enough attention from the state or businesses.

At the same time, there has been growth in the number of innovation enterprises ( $2 \%$ over 5 years) and significant growth in scientific research financing (almost doubling over 5 years). However, in view 
Table 4. Results of our analysis on innovation development in present-day Russia based on the proprietary methodology proposed

\begin{tabular}{lcccc}
\hline $\begin{array}{l}\text { Indicators of innovation development } \\
\text { in Russia }\end{array}$ & $\mathbf{2 0 1 0}$ & $\mathbf{2 0 1 4}$ & Integral & Assigned values \\
\hline \multicolumn{4}{c}{ Indicators of current levels of innovation development in economic systems } \\
\hline IE & 3,536 & 3,605 & - & - \\
Number of enterprises in thousands & $4,823.3$ & 4,886 & - & $\mathbf{1}$ \\
SE, \% & - & $\mathbf{0 . 0 7}$ & - \\
FS & 225.762 & 425.302 & - & - \\
GDP of Russia, RUB billion & 82,055 & 126,186 & - & $\mathbf{1}$ \\
SF, \% & - & $\mathbf{0 . 3 4}$ & $<0.5 \%$ & - \\
CT & - & 1,409 & - & - \\
IT & - & 191,372 & $\mathbf{2}$ \\
IT/CT & - & $\mathbf{1 3 5 . 8 2}$ & $>100$ \\
\hline
\end{tabular}

Indicators of possibilities and perspectives on innovation development in economic systems for the near future

\begin{tabular}{|c|c|c|c|c|}
\hline $\mathrm{IE}_{2014} / \mathrm{IE}_{2010}$ & - & 1.02 & $1.00-1.19$ & 3 \\
\hline QP, one thousand people & 742 & 727 & - & - \\
\hline $\mathrm{QP}_{2014} / \mathrm{QP} 2010$ & - & 0.98 & $0.80-0.99$ & 2 \\
\hline $\mathrm{FS}_{2014} / \mathrm{FS}_{2010}$ & - & 1.88 & $>1.50$ & 5 \\
\hline
\end{tabular}

Note: Adapted from "Russia in numbers. Scientific research and innovations 2015: Bulletin of Rosstat" by Rosstat (2015). Retrieved from Retrieved from http://www.gks.ru/free_doc/doc_2015/rusfig/rus-15.pdf

of inflation, this growth trend is brought down to zero and is thus nominal, and this is aggravated by a decline in the number of employees conducting scientific research (a $2 \%$ decline over 5 years). The equation for the 2014 index of innovation development in Russia takes the following form:

$\operatorname{Iinnov}($ Russia2014 $)=1+1+2+3+2+5=14$.

The retrieved index of innovation development value shows low current levels and a lack of views on innovation development. Russian economic modernization strategies and an orientation toward innovation development have positive effects and should improve conditions in future years. From the developed approach, we propose the following optimal model of innovation development for modern economic systems (Fig. 1).

Fig. 1 shows that the proposed model can be visualized as a pyramid reflecting the dependence of past and current levels of innovation development in economic systems and their current potential and future development. This format allows one to conduct complex analyses in view of dynamics and tendencies of innovation development, modeling, and change forecasting. The model applies instruments of innovation development such as the financing of science and the creation and application of innovations by means of the development of economic system human capital. 


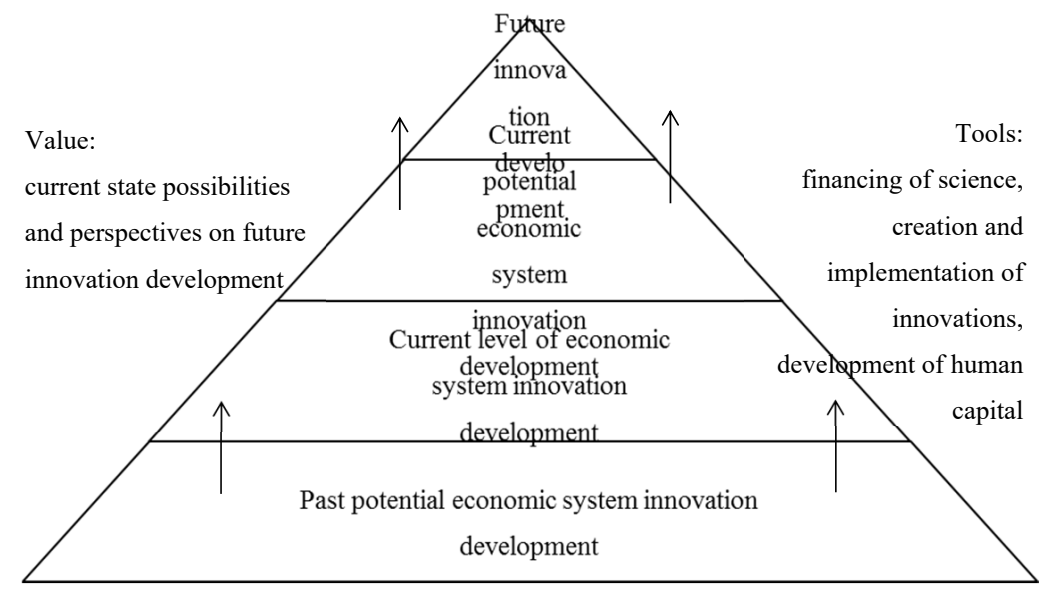

Figure 1. Optimal model of innovation development in modern economic systems

\section{Conclusion}

We conclude that at present, there are three approaches to the analysis of theoretical and methodological aspects of innovation development in modern economic systems. These methods can be classified based on theoretical views of innovation development in modern economic systems and certain methods as follows: the plan-factual approach, whereby innovation development in economic systems is understood as the degree of plan realization; the ranking approach, through which innovation development in economic systems is measured based on rankings; and the index approach, by which innovation development in an economic system is understood as an index value.

These approaches present unique advantages and serious disadvantages by disregarding future innovation development and orientation in economically developed countries. As a means of overcoming these drawbacks, we presented a new approach that involves the simultaneous evaluation of current levels and determinations of potential innovation development in economic systems. We apply the proposed methodology through an analysis of innovation development in modern economic systems based on the case of present-day Russia, revealing limited perspectives on future innovation development and probable improvements as a result of state modernization programs and innovation development strategies.

We present a new methodology for the analysis of innovation development in modern economic systems that involves the calculation of an index of innovation development that reflects current levels of innovation development in economic systems and possibilities for and perspectives on innovation development in economic systems to emerge in the near future.

Our validation of the proposed methodology through the case of present-day Russia revealed the country's weak innovation development plans but probable improvements to this situation as a result of state modernization programs and innovation development strategies. Our calculation of the 2014 index of innovation development for Russia revealed that inno- 
vation development does not receive enough attention in Russia from the state and businesses.

The developed approach involves the use of an optimal model of innovation development in modern economic systems. The model applies instruments of innovation development such as the financing of science and the creation and application of innovations by means of the development of economic system human capital.

Our approval of the proposed methodology was ensured for the provision of its clarity and is limited the presented analysis of the Russian economy; the proposed model of optimal innovation development in economic systems is practically oriented but is theoretical in nature, limiting the results of the research conducted. Hence, in future research studies, the proposed approach should be used for the analysis of state views on innovation development in various economic systems and the creation of innovation development strategies for modern economic systems.

\section{References}

Allan, R., Crouchley, R., Robertson, A. (2012). Collaborative and distributed innovation and research in business activity. In A. A. Juan, T. Daradoumis, M. Roca, S. E. Grasman, \& J. Faulin (Eds.), Collaborative and distributed e-research: Innovations in technologies, strategies and applications (pp. 310329). Hershey, PA: IGI Global.

Al-Sudairi, M., Bakry, S.H. (2014). Knowledge issues in the global innovation index: Assessment of the state of Saudi Arabia versus countries with distinct development. Innovation: Management, Policy and Practice, 16(2), 176-183

Batkovskiy, A. M., Konovalova, A. V., Semenova, E. G., Trofimets, V. J., Fomina, A. V. (2015). Study of economic systems using the simulation-based statistical modeling method. Mediterranean Journal of Social Sciences, 6(4), 369-380.

Bayev, I. A., Podshivalova, M. V. (2013). Tasks of institutional support to increase innovation activity of small business in the region. Economy of Region, 2013(1), 189-198.

Belkin, V.N., Belkina, N.A. (2013). Ways of increasing enterprises' innovation activity. Economy of Region, 2013(1), 238-242.
Coccia, M. (2015). General sources of general purpose technologies in complex societies: Theory of global leadership-driven innovation, warfare and human development. Technology in Society, 42, 199-226.

Donate, M. J., Peña, I., Sánchez de Pablo, J. D. (2016). HRM practices for human and social capital development: effects on innovation capabilities. International Journal of Human Resource Management, 27(9), 928-953.

Economist Intelligence Unit (2015). New global classification of the most innovationally developed countries. Retrieved from http://www.enter. ie.edu/cms/en/o/6469/1

European Commission (2014). European innovation scoreboard 2014. Retrieved from http://ec.europa. eu/growth/industry/innovation/facts-figures/ scoreboards_en

Filinova, N. V., Filinov, V. P., Pogodina, O.N.,Lunev, V.A., Luneva, E. V. (2015). The socio-economic foundations of the development of contemporary economic innovations. Asian Social Science, 11(6), 150-160.

$\mathrm{Hu}, \mathrm{Z}$. P. (2013). On the value orientation of modern market economic system. In D. Li (Ed.), Values of Our Times: Contemporary Axiological Research in China (pp. 231-238). Berlin: Springer Verlag.

Imanbekova, M. (2014). The use of foreign experience in forming system state regulation of innovation activities of enterprises in the Republic of Kazakhstan. World Applied Sciences Journal, 30(5), 630-634.

Kolychev, V. D., Prokhorov, I. V. (2015). Conception, technology and methods of development of university system of innovation projects commercialization based on effectuation. Asian Social Science, 11(8), 44-51.

Loasby, B. J. (2015). Knowledge and Organisation in Economics and Economic Systems: A Research Tradition. Managerial and Decision Economics, 36(1), 6-15.

Machado Arroio, A. C. (2012). Governance of science, technology and innovation programmes for development is global financing getting it right? Institutions and Economies, 4(2), 45-64.

Management Today (2013). Global innovational index: More on methodology. Retrieved from http:// www.managementtoday.co.uk/news/610009 
Mishra, S., Narayan, P. K. (2015). A nonparametric model of financial system and economic growth. International Review of Economics and Finance, 39, 175-191.

Morozova, I.A. Poluyufta, L.V. (2014). (2014). The use of subcontracting mechanisms in education as means of the increase of business and innovation activity of higher education institutions. World Applied Sciences Journal, 31(5), 884-888.

Nechaev, A., Antipina, O. (2015). Tax stimulation of innovation activities enterprises. Mediterranean Journal of Social Sciences, 6(1S2), 42-47.

Ng, B. K.,Kanagasundram, T., Wong, C. Y., Chandran, V. G. R. (2015). Innovation for inclusive development in Southeast Asia: The roles of regional coordination mechanisms. The Pacific Review, 29(4), 573-602.

Okrepilov, V. V., Makarov, V. L., Bakhtizin, A. R., Kuzmina, S. N. (2015). Application of supercomputer technologies for simulation of socioeconomic systems. Economy of Region, 2015(2), 301-313.

Oxenstierna, S. (Ed.). (2015). The Challenges for Russia's Politicized Economic System. London, UK: Routlege.

Parrilli, M. D., Nadvi, K.,Yeung, H. W. C. (2013). Local and regional development in global value chains, production networks and innovation networks: A comparative review and the challenges for future research. European Planning Studies, 21(7), 967-988.

Popkova, E. G, Zubakova, N. N., Bogdanov, D. V., Yakovleva, E. A, Nebesnay, A. Y. (2013). Measurement of economic growth as a factor of development of strategies of economic transformation. World Applied Sciences Journal, 25(2), 264-269.

Popkova, E. G., Yurev, V., Stepicheva, O., Denisov, N. (2015). Transformation and concentration of intellectual capital as a factor of economic growth in the modern economy. Regional and Sectoral Economic Studies, 16(1), 53-60.

Rommel, J. (2015). What can economic experiments tell us about institutional change in social-ecological systems? Environmental Science and Policy, 53, 96-104.

Rosstat. (2015). Russia in numbers. Scientific research and innovations 2015: Bulletin of Rosstat.
Retrieved from http://www.gks.ru/free_doc/ doc_2015/rusfig/rus-15.pdf

Rumyantsev, A. A. (2015). Science and innovation space of a macroregion: Prospects of innovative territorial development. Studies on Russian Economic Development, 26(4), 379-387.

Ryapukhina, V. N., Suprun, E. V.,Doroshenko, Y. A., Bukhonova, S. M., Somina, I. V. (2015). Strategy of effective management for small businesses at different stages of innovation activity. Journal of Applied Engineering Science, 13(2), 117-125.

Ryneiska, L. (2014). The world innovation economy: Modern trends of development. Economic Annals-XXI, 7-8, 8-11.

Saikevych, M. I. (2012). Dualism of modern economic system. Actual Problems of Economics, 132(6), 9-15.

The World Bank (2015). Knowledge for Development Program. Retrieved from https://openknowledge. worldbank.org/bitstream/handle/10986/22550/ WBAnnualReport2015EN.pdf

Tovt, T. I. (2014). Regulation mechanism for investment support of innovation activities of enterprises. Actual Problems of Economics, 152(2), 211-218

Turriago-Hoyos, A., Thoene, U., Bernal-Torres, C., Alfonso-Lizarazo, E. (2015). Product innovation, research and development and technology acquisition: A case study of the industrial sector in Colombia. Institutions and Economies, 7(2), 85-119.

Vasin, S. M., Gamidullaeva, L. A. (2015). Development a basic model of the innovation system. Review of European Studies, 7(11), 175-183.

Voegtlin, C., Scherer, A. G. (2015). Responsible innovation and the innovation of responsibility: Governing sustainable development in a globalized world. Journal of Business Ethics. Doi: 10.1007/ s10551-015-2769-z.

World Economic Forum (2014). Report on global competitiveness for 2014. Retrieved from http:// www.weforum.org/en/initiatives/gcp/Global\%20 Competitiveness\%20Report/index.htm

Yakovleva, E. A., Azarova, N. A., Titova, E. V. (2015). Innovation as a vector of regional economic development and a necessary condition for the 
progress of the world economy. Asian Social Science, 11(20), 90-96.

Zakharova, E. N., Prokhorova, V. V., Shutilov, F. V., Klochko, E. N. (2015). Modern tendencies of cluster development of regional economic systems. Mediterranean Journal of Social Sciences, 6(5S3), 154-163. 